\title{
Dietary protein requirements for juvenile sole Solea aegyptiaca (Chabanaud, 1927)
}

\author{
Abdel moneim M.Yones ${ }^{1}$ and Nabil F. Abdel-Hakim ${ }^{2}$ \\ 1-National Institute of Oceanography \& Fisheries, Shakshouk Fish Research \\ Station, El -Fayoum, Egypt \\ E. mail: yones 552000@yahoo.com
}

2-Department of animal production, Faculty of Agriculture, Al-Azhar University

\begin{abstract}
$\prod$ for he present study was conducted to determine the dietary protein requirement for optimal growth performance and body composition of juvenile sole fish. Four diets were formulated with different protein levels (D40, D45, D50 and D55\% crude protein). The silverside fish (Atherina boyeri) was added to the diets as local animal protein source and to enhance palatability of the test diets. Fish were fed the artificial diets as $2 \%$ of the fish biomass daily divided into two equal portions. Juvenile sole with an initial weight of $(6.65 \pm 0.2 \mathrm{~g})$ were distributed as 40 juveniles in each triplicate tank, each of $1 \mathrm{~m}^{3}$ volume. The experimental period lasted 120 days after start. The results showed significant differences $(\mathrm{P}<0.05)$ in growth performance and feed efficiency between diets. The highest performances in terms of (Finial weight, Weight gain, Average daily gain, Specific growth rate, Condition factor, Feed conversion ratio, Protein efficiency ratio, Protein productive value and Hepatosomatic index) were obtained with the D55\% CP, followed by D50\%, without significance difference between them. However, fish fed D40\% crude protein diet recorded less performance parameters. No significance difference $(\mathrm{P}<0.05)$ in whole body chemical composition (dry matter, crude protein, crude lipid and ash) were found between fish fed all experimental diets. However, slight increase in whole body lipid contents were recorded with D50\%CP and D55\%CP levels. The results of the present study indicated that, D55\% crude protein level can be optimal for meeting the requirement of juvenile sole, Solea aegyptiaca without adverse effects on growth performance and feed efficiency.
\end{abstract}

Key words: Solea aegyptiaca, silverside, protein requirement, stomach content, growth performance

\section{INTRODUCTION}

The fish culture has expanded extensively in the last few years, but this growth can mainly be attributed to the culture of a new marine species which already show market demanded increase. Scientific and technical interests have been focused on high native marine species, whose biological cycle can be reproduced using currently available breeding techniques such as sole (Solea solea,Linnaeus,1758). 
The consistently high price attracted by sole in European markets has repeated by stimulated attempts to develop rearing methods for this species, the earliest dating back to earliest years of the last century (Fabre-Domergue and Bietrix, 1905). Although these authors were met with limited success, farming only became a realistic aspiration following the demonstration that the juveniles could be reared in large numbers using Artemia nauplii as food (Shelbourne, 1975). Cultivation of Solea vulgaris has been achieved in France and the UK since the seventies (Shelbourne, 1975). Many studies during the 1970-1980 period demonstrated that juvenile sole could be weaned from live food to formulated feeds and that success was dependent largely on the inclusion of either invertebrate tissues (Bromley, 1977 and Metailler et al., 1981) and/or chemical taste attractants (Metailler et al., 1983).

Thirty years ago, sole fish was already considered one of the most interesting and promising species for marine fish farming in Europe (Howell, 1997). The species however, never become a commercial success, due to technological and culture problem disease and the fact that this species requires warm water ( 20) for optimal growth in the juvenile and on-growing stages. This means that our culture area in Egypt is temperate and suitable for rearing sole. On the other hand, the advanced feed technology for weaning and ongrowing stages are developed and led a renewed interest in sole as an aquaculture species (Howell,1997, Dinis et al.,1999). The soles (Soleidae) assume to take a very important place in the Egyptian Mediterranean fisheries, where Egyptian sole (Solea aegyptiaca) is the most common species of soles that contributed about $6.5 \%$ of the total catch of trawl fishery, forming about $13 \%$ of the gross revenue of the trawling (Mehanna, 2007).

Kariman (2009) recorded that catch composition of Sole species during summer and winter seasons in lake Qarun were more than 50 and 35\%, respectively. However, Eisawy and El-Bolock (1975) indicated that S. vulgaris spawned and propagated successfully in lake Qarun and it makes up about 36\% of the total catch of lake.

Studies on stomach contents of Solea sengaleses showed a dominance of polychaetes (Hediste diversicolor) but some Amphipods and Isopods were also identified (Bernardo, 1990). The highest densities of sole were recorded in deep, warm, low salinity area with sediment of fine sand and high abundance of amphipods (Cabral and Costa, 1999). In lake Qarun, S. aegyptiaca feeds mainly on macrobenthos. The polychate Neries succinea seems to be the most preferred items species for sole, since it formed about 39.9 and $31.1 \%$ of its total food items during 1980 and 1995 (El-Shabrawy and Ahmed, 2007). Braber and de Groot (1973) mentioned that, the diet of Solea solea (=S. vulgaris) from Ebroestuary consisted mainly of polychaetes, crusraceans and mollusks. In contrast, the findings of the above authors (where polychaetes were the most important prey items of sole), crustaceans were the most important prey of $S$. solea in Bardawil lagoon (Sabrah, 2004). 
The effect of chemical stimuli on the feeding of larval sole has been investigated by Knutsen (1992), who found that in sole larvae, the most potent substances were L-phenylalanine, L-lysine, L-aspragine, inosine-5monophosphate and butane as feed attractant. The results of the same author show that feeding of sole larvae is influenced by chemosensory processes at the early larval stage and that chemoreception may be an integrated part of sole feeding strategy. Cadena-Roa et al. (1982) investigated the use of attractive substances in feed to increase the feed intake of sole during weaning. They used extruded pellets because these are soft, palatable, resistant to leaching and can be sized. During a 45 days experiment, extruded pellets containing only water, oils and vitamins, were compared with pellets mixed with the following additives: ground mollusks, ground artemia, ground polychaetes, mixture of glycine, Lalanine, L-glutamic acid, L-arginine, butane and inosine. They gave a better growth and survival than the control. Metailler et al. (1983) recorded that, butane, glycine and inosine gave the best results as attractants. Day et al. (1997) found that the survival of sole during weaning period was positively correlated to the level of hydrolyzed fish protein concentrate.

Appelbaum (1985) concluded that a certain proportion of a population of sole can be reared from eggs to juvenile fishes fed only a formulated diet. Day et al. (1999) using a commercial larval feed for weaning sole and recorded a growth rates comparable to those found for groups fed on live foods. Coutteau et al. (2001) evaluated the potential of formulated feed developed specifically fore sole and compared it with a commercial turbot feed for on-growing $S$. senegalensis. They reported that the optimum diet for sole was a sinking extruded particles with a crude protein to crude fat ratio of 55/16 and a mixture of selected attractants to enhance attractability.

The protein requirements for maximum growth of turbot, sole, plaice and Atlantic halibut ranges between $50 \%$ and $65 \%$ of diet (Berge and Storebakken, 1991, Guillaune et al. 1991, Aksnes et al.1996). The dietary protein requirement for these flatfishes species during the juvenile stage is still scarce (Dais et al. 2004, Rubio et al. 2009). Some research has recently been achieved for $S$. senegalensis (Rema et al. 2008 and Rubio et al. 2009) establishing optimal protein and lipid levels for growth. Less information is currently available for common sole (S. solea) nutrition (Piccolo et al. 2008).

The present study aims to establish and investigate the dietary protein requirement for optimum growth and body composition of juvenile sole Solea aegyptiaca reared in fiber glass tanks.

\section{Fish culture and experimental diets}

\section{MATERIALS AND METHODS}

The present study was conducted using the research facilities of the experimental station at Shakshouk, Fayoum Governorate, National Institute of Oceanography and Fisheries (NIOF). The system contained two water pumps 
and two upstream sandy filter units at a point between the water source and tanks. Each pump was drowning the water from Qarun lake to the storage tanks and forced it to the rearing tanks in open system. Physicochemical characteristics of water tanks were examined every two weeks according to APHA (1992).

Juvenile Solea aegyptiaca were caught from Qarun lake and transferred to the laboratory of the station. Artemia nauplii were obtained from Emisal company in Shakshouk and used as live feeds in the first days, then it was gradually replaced by the experimental diets within two weeks of acclimatization period. Juvenile Solea with an average initial weight of $6.65 \pm 0.2 \mathrm{~g}$ were randomly distributed and stocked at 40 juvenile/tank in 12 fiber glass tanks with a volume of $\left(1 \mathrm{~m}^{3}\right)$ each representing four protein levels (D40,D45,D50 and D55\%) in triplicates. The fiber glass tanks were provided by sand layer of $10 \mathrm{~cm}$ in the bottom.

Four diets were formulated in order to test four levels (D40, D45, D50 and D55\%) of crude protein on growth performance and nutrients utilization of Solea aegyptiaca. Silverside (Atherina boyeri) were obtained from local market in Shakshouk, then dried and ground to use it in feed formulation as a local ingredients to replace imported fish meal and enhance diet palatability. All diets were processed into dry sinking pelleted form, using California pelleting machine with $2 \mathrm{~mm}$ diameter. The experimental diets were fed at $2 \%$ rate of live body weight (BW) twice daily at 10.00 a.m and 16.00 p.m. The experimental treatments were triplicated and lasted 120 days after start.

\section{Growth performance}

The following growth performance parameters were calculated as follows:

- Specific growth rate $=100 \times($ Ln final weight-Ln initial weight $) / 120$.

- Condition factor $\left(\mathrm{g} / \mathrm{cm}^{-3}\right)=($ wet weight $) /\left(\right.$ total length $\left.{ }^{-3}\right) \times 100$.

- Feed conversion= (feed given per fish)/ (weight gain per fish).

- Protein efficiency ratio = (weight gain per fish)/ (protein intake per fish).

- Protein productive value $(\%)=100$ (protein gain / protein fed).

-Hepatosomatic index (HIS \%) $=$ (liver weight) $/($ fish weight $) \times 100$.

\section{Chemical analysis}

The silverside fish used in feed formulation, the experimental diets and fish carcass were dried for subsequent protein (kieldahl), ether extract (Soxhlet) and moisture analysis, according to AOAC (1995) methods. Protein levels were calculated by multiplying the total nitrogen $(\mathrm{N})$ with 6.25 . Nitrogen free extract was calculated based on the difference between the dry matter content minus protein, fat and ash content according to AOAC (1995). Amino acid composition of silverside fish was determined by High Performance Liquid Chromatography (HPLC), following acid-hydrolysis of samples. For amino acids analysis, silverside fish was hydrolyzed with $6 \mathrm{~N} \mathrm{HCl}$ at $110^{\circ} \mathrm{C}$ for $24 \mathrm{~h}$ for the chromatographic separation using the HPLC as described by Gardner and Miller 
(1980). Tryptophan was determined calorimetrically in alkaline hydrolysate according to the method described by Blauth et al.(1963).

Fatty acids, total lipids were extracted according to Folech et al.(1957). Fatty acid methyl esters were prepared by acid-catalyzed transmethylation of total lipids (Shantha and Ackman,1990). They were analyzed in a Varian 3400 gas chromatograph, (equipped with a wax fused capillary Column (30 mx 0.25 $\mathrm{mm}$ i.d, film thickness, $0.25 \mathrm{Mm}$, Jw, USA), using helium as carrier gas (1.2 $\mathrm{ml} / \mathrm{min}$ ) and thermal gradient from 180 to $240^{\circ} \mathrm{C} / \mathrm{min}$. injector and flam ionization detector temperature were 260 and $250^{\circ} \mathrm{C}$, respectively. Data were recorded on spectra physics 4270 integrator. Identification of individual fatty acid was made by comparison with known standard mixture.

Gross energy ( $\mathrm{MJ} \mathrm{Kg}^{-1}$ diet) was calculated according to Lozano et al.(2007) using the following calorific values: $23.9,39.8$ and $17.6 \mathrm{KJ} \mathrm{Kg}^{-1}$ diet for protein, ether extract and nitrogen free extract, respectively. The metabolizable energy contents of the experimental diets were calculated as 18.9, 35.7 and $14.7 \mathrm{KJ} \mathrm{Kg}^{-1}$ diet for protein, lipid and nitrogen free extract, respectively according to Jobling (1994).

\section{Statistical analysis}

One way Analysis of Variance (ANOVA) was applied to test the effect of different dietary protein levels on various growth parameters, nutrient utilization and chemical composition of experimental fish according to Snedecore and Cochran (1987). Duncan Multiple Range test was used to detect the significant differences between the means of treatments (Duncan, 1955). All analysis were performed using SAS (version 6, 1986 SAS Institute, Cary, NC, USA).

\section{Physicochemical characteristics}

\section{RESULTS}

Water physicochemical characteristics (Table 1) revealed that temperature, $\mathrm{pH}$, dissolved oxygen, salinity and unionized ammonia are within the optimum ranges for rearing sole according to Fonds (1976). Similar physicochemical condition were observed in all tanks.

Table 1: An averages of water physicochemical characteristics parameters during experimental period.

\begin{tabular}{|l|l|l|l|l|}
\hline \multirow{2}{*}{ Parameters } & \multicolumn{4}{|c|}{ Diets } \\
\cline { 2 - 5 } & \multicolumn{1}{|c|}{ D40 } & \multicolumn{1}{|c|}{ D45 } & \multicolumn{1}{c|}{ D50 } & \multicolumn{1}{c|}{ D55 } \\
\hline Temperature ${ }^{\mathbf{0}} \mathbf{C}$ & $24.0 \pm 0.31$ & $24.1 \pm 0.30$ & $24.2 \pm 0.32$ & $24.2 \pm 0.31$ \\
\hline pH & $7.4 \pm 0.15$ & $7.3 \pm 0.11$ & $7.3 \pm 0.14$ & $7.6 \pm 0.13$ \\
\hline Dissolved oxygen (mg/l) & $6.5 \pm 0.11$ & $6.4 \pm 0.14$ & $6.3 \pm 0.16$ & $6.4 \pm 0.11$ \\
\hline Salinity \%o & $35.13 \pm 0.11$ & $35.14 \pm 0.15$ & $35.12 \pm 0.13$ & $35.12 \pm 0.13$ \\
\hline Unionized ammonia (mg/l) & $0.021 \pm 0.01$ & $0.022 \pm 0.001$ & $0.020 \pm 0.001$ & $0.021 \pm 0.001$ \\
\hline
\end{tabular}




\section{Chemical composition of silverside (Atherina boyeri) and diets Protein,} Amino acids and Fatty acids

Results of the chemical composition of Atherina boyeri are shown in (Table 2). They showed a high protein (19.3\% w/w basis), moderate lipid (6.5\% w/w basis) and low ash contents (2.4\% w/w basis). Results of (Table 3) revealed that the highest value of amino acids were detected for glutimic acid (8.2\%) followed by threonine (6.6\%). In the same trend, the essential amino acids presented in (Table 3) indicate that all essential amino acids in silverside fish were almost of the same profile of the commercial imported fish meal in the Egyption market except that a slight increase in arginene as an essential amino acids and high value of glutimic acid compared with silverside fish, where silverside fish is higher in theronine as essentional amino acid compared to commercial fish meal. As shown in (Table 4), Saturated fatty acids (SFA) in Atherina boyeri constitute the majority of the fatty acids pool, followed by monounsaturated (MUFA) and polyunsaturated (PUFA) fatty acids, respectively. As presented in (Table 5), the experimental diets were different in their protein contents from (40-55\%) and (20.59-22.24 MJ kg-1 diets) for gross energy.

Table 2: Chemical whole body composition of Atherina boyeri caught from Qarun lake (\%w/w basis).

\begin{tabular}{|l|c|l|c|}
\hline \multicolumn{1}{|c|}{ Parameters } & $\begin{array}{c}\text { (\%w/w } \\
\text { basis) }\end{array}$ & Parameters & (\%w/w basis) \\
\hline Dry matter & 28.2 & Lipid & 6.5 \\
\hline Protein & 19.3 & Ash & 2.4 \\
\hline
\end{tabular}

Table 3: Amino acids composition (g/100g crude protein) of silverside Atherina boyeri caught from Qarun lake and commercial fish meal.

\begin{tabular}{|c|c|c|c|c|c|}
\hline $\begin{array}{c}\text { Amino acids (g/100g } \\
\text { crude protein) }\end{array}$ & Silverside & Fish meal* & $\begin{array}{c}\text { Amino acids (g/100g crude } \\
\text { protein) }\end{array}$ & Silverside & Fish meal* $^{*}$ \\
\hline Arginine & 5.24 & 6.4 & Tyrosine & 2.4 & 2.6 \\
\hline Histidine & 1.8 & 2 & Threonine & 6.6 & 3.9 \\
\hline Isolucine & 4.3 & 3.7 & Trptyophane & 1.5 & 0.9 \\
\hline Leucine & 5.8 & 6.5 & Valine & 4.3 & 4.5 \\
\hline Lysine & 6.7 & 6.9 & Alanine & 5.6 & 6.3 \\
\hline Methionine & 2.7 & 2.6 & Glutimic acid & 8.2 & 12.8 \\
\hline Cystine & 0.7 & 0.9 & Aspartic acid & 7.3 & 8.5 \\
\hline Phenylalanine & 3.1 & 3.3 & Serine & 4.5 & 4.8 \\
\hline
\end{tabular}

*Windsor (2001). 
Table 4: Fatty acids composition (\% of total fatty acids) of silverside Atherina boyeri caught from Qarun lake.

\begin{tabular}{|l|c|l|c|c|c|}
\hline Fatty acid & $\%$ & Fatty acid & $\mathbf{\%}$ & Fatty acid & $\%$ \\
\hline C14: 0 & 6.2 & $\mathbf{C 1 6 : 2 n - 4}$ & 0.95 & $\mathbf{C 2 2 : 6 n - 3}$ & 7.22 \\
\hline C16:0 & 28.2 & $\mathbf{C 1 6 : 3 n - 4}$ & 0.93 & SFA & 39.6 \\
\hline C18:0 & 5.21 & $\mathbf{C 1 8 : 2 n - 6}$ & 4.32 & MUFA & 24.54 \\
\hline C16: $\mathbf{1 n}-\mathbf{7}$ & 6.85 & $\mathbf{C 1 8 : 4 n - 3}$ & 1.76 & PUFA & 23.4 \\
\hline C18:1n-9 & 13.54 & $\mathbf{C 2 0 : 4 n - 6}$ & 1.25 & $\mathbf{\Sigma}-\mathbf{n}-3$ & 16.95 \\
\hline C18:1n-7 & 1.6 & $\mathbf{C 2 0 : 5 n - 3}$ & 6.11 & $\mathbf{\Sigma}-\mathbf{n}-6$ & 5.57 \\
\hline C20:1n-9 & 2.55 & $\mathbf{C 2 2 : 5 n - 3}$ & 0.86 & & \\
\hline
\end{tabular}

Table 5: Formulation and chemical composition of the experimental diets.

\begin{tabular}{|l|c|c|c|c|}
\hline \multirow{2}{*}{ Ingredientes } & \multicolumn{4}{c|}{ Diets } \\
\cline { 2 - 5 } & $\mathbf{D 4 0}$ & $\mathbf{D 4 5}$ & $\mathbf{D 5 0}$ & D55 \\
\hline Silverside meal & 20 & 25 & 35 & 45 \\
\hline Poultry-by-product meal & 20 & 25 & 30 & 36 \\
\hline Soybean meal & 15 & 20 & 15 & 5 \\
\hline Corn gluten meal & 15 & 10 & 5 & 4 \\
\hline Wheat bran & 20 & 10 & 5 & - \\
\hline Fish oil & 3 & 3 & 3 & 3 \\
\hline Sunflower oil & 3 & 3 & 3 & 3 \\
\hline Vitamin/ Mineral Mix ${ }^{1}$ & 2 & 2 & 2 & 3 \\
\hline CMC (carboxy methyl cellulose & 2 & 2 & 2 & 2 \\
\hline Total & $\mathbf{1 0 0}$ & $\mathbf{1 0 0}$ & $\mathbf{1 0 0}$ & $\mathbf{1 0 0}$ \\
\hline Chemical composition (\%) & & & & \\
\hline Dry matter & 93.5 & 93.5 & 91.8 & 92.4 \\
\hline Crude protein & 40 & 45 & 50 & 55 \\
\hline Ether extract & 14.26 & 15.14 & 16.85 & 18.06 \\
\hline Nitrogen free extract & 30.47 & 24.12 & 17.5 & 10.94 \\
\hline Fiber & 4.54 & 3.47 & 1.86 & 1.25 \\
\hline Ash & 10.73 & 12.27 & 13.79 & 14.75 \\
\hline Gross energy MJ kg ${ }^{-1}$ diets $^{\mathbf{2}}$ & 20.59 & 21.01 & 21.73 & 22.24 \\
\hline ME (MJ kg (diet) $^{\mathbf{3}}$ & 17.09 & 17.44 & 18.03 & 18.43 \\
\hline
\end{tabular}

1-Vitamin-mineral premix, (mg or $\mathrm{g} \mathrm{Kg}^{-1}$ dry diets); vitamine B12,0.1mg; vitamne k,10mg; inositol,800mg, pantochenic acid,60mg; niacin acid,200mg; thiamin, 20mg; riboflavin,40mg; pyridoxine HCL,20mg; folic acid,29mg; biotin,120mg; retinol acetate,32mg; cholecalciferol, $5 \mathrm{mg} \alpha$-tocopheryl-acetate, $120 \mathrm{mg}$; ascorbic acid,2000mg; choline chloride, 2500mg; ethoxyquin, 150mg, KH2PO4, 22mg; FeSO47 $\mathrm{H}_{2} \mathrm{O}$, 1mg; Zn SO $47 \mathrm{H}_{2} \mathrm{O}, 0.13 \mathrm{mg} ; \quad \mathrm{Mn}$ SO $44 \mathrm{H}_{2} \mathrm{O}$, 52.8mg; $\mathrm{CuSO} 45 \mathrm{H}_{2} \mathrm{O}, 12 \mathrm{mg} ; \mathrm{Ki}, 2 \mathrm{mg}$.

2-Lozano et al. (2007).

3-Jobling (1994). 


\section{Growth performance}

As presented in (Table 6), averages of initial weights ranged between 6.4 to $6.9 \mathrm{~g} /$ fish with insignificant differences among the dietary groups indicating the random distribution of the experimental fish among treatment groups. Concerning growth performance parameters (Table 6) the highest finial weights of sole fish $(\mathrm{P}<0.05)$ were recorded by $\mathrm{D} 55 \%$ and $\mathrm{D} 50 \%$ groups followed in a significant decreasing order by D45\% and D40\%, respectively, however differences in final weights among D50 and D55 groups were insignificant. The same trend was observed with total gain, daily gain and specific growth rate, where D55\% and 50\% groups recorded the highest values followed in a significant $(\mathrm{P}<0.05)$ decreasing order by $\mathrm{D} 45$ and $\mathrm{D} 40$, respectively. As shown in the same table, groups D55 and D50 recorded significantly $(\mathrm{P}<0.05)$ higher values of condition factor compared to the D45 and D40 groups, indicating that the two former groups (D55 and D50) grow better in weight than in length. Results of survival rate (Table 6) were 98\% for all dietary treatments groups indicating that the tested diets had no effects on sole fish survival rates, thus all mortalities were due to accidental factors during recording the fish weight every two weeks to adjust the feed amounts.

Table 6: Growth performance mean values of Solea aegyptiaca fed the experimental diets.

\begin{tabular}{|l|c|c|c|c|}
\hline \multirow{2}{*}{ Parameters } & \multicolumn{4}{|c|}{ Diets } \\
\cline { 2 - 5 } & $\mathbf{D 4 0}$ & $\mathbf{D 4 5}$ & $\mathbf{D 5 0}$ & $\mathbf{D 5 5}$ \\
\hline Initial aveg. Weight (g/fish) & $6.5^{\mathrm{a}}$ & $6.4^{\mathrm{a}}$ & $6.9^{\mathrm{a}}$ & $6.8^{\mathrm{a}}$ \\
\hline Final aveg. Weight (g/fish) & $33.8^{\mathrm{c}}$ & $35.4^{\mathrm{b}}$ & $44.4^{\mathrm{a}}$ & $44.9^{\mathrm{a}}$ \\
\hline Total gain (g/fish) & $27.3^{\mathrm{c}}$ & $29.0^{\mathrm{b}}$ & $37.5^{\mathrm{a}}$ & $38.1^{\mathrm{a}}$ \\
\hline Average daily gain (g/fish/day) & $0.22^{\mathrm{c}}$ & $0.24^{\mathrm{b}}$ & $0.31^{\mathrm{a}}$ & $0.31^{\mathrm{a}}$ \\
\hline Specific growth rate & $1.19^{\mathrm{c}}$ & $1.25^{\mathrm{b}}$ & $1.59^{\mathrm{a}}$ & $1.57^{\mathrm{a}}$ \\
\hline Condition factor (g/cm $\left.{ }^{-3}\right)$ & $1.28^{\mathrm{b}}$ & $1.29^{\mathrm{b}}$ & $1.32^{\mathrm{a}}$ & $1.33^{\mathrm{a}}$ \\
\hline Survival rate \% & 98 & 98 & 98 & 98 \\
\hline Feed consumed (g/ fish) & 48.0 & 46.0 & 45.0 & 44.0 \\
\hline Feed conversion ratio & $1.75^{\mathrm{c}}$ & $1.58^{\mathrm{b}}$ & $1.20^{\mathrm{a}}$ & $1.15^{\mathrm{a}}$ \\
\hline Protein efficiency ratio(PER) & $1.42^{\mathrm{c}}$ & $1.4^{\mathrm{c}}$ & $1.51^{\mathrm{b}}$ & $1.73^{\mathrm{a}}$ \\
\hline Protein Productive Value (PPV\%) & $27.55^{\mathrm{b}}$ & $27.2^{\mathrm{b}}$ & $32.52^{\mathrm{a}}$ & $32.90^{\mathrm{a}}$ \\
\hline HIS (\%) & $1.12^{\mathrm{a}}$ & $1.13^{\mathrm{a}}$ & $1.14^{\mathrm{a}}$ & $1.15^{\mathrm{a}}$ \\
\hline
\end{tabular}

Means in the same row with different superscript letters are significantly different $(\mathrm{P}<0.05)$.

* Non-consumed portion of food was collected, dried and deducted from total given ration.

As can be seen in (Table 6), average amounts of feed consumed were found to be 48.0, 46.0, 45.0 and 44.0g for fish fed D40\%CP,D45\%CP, D50\%CP and D55\%CP, respectively, which indicate slight increases in feed consumption 
with fish fed D40\%CP and D45\%CP compared to the D50\% and D55\% CP. On the other hand, the best FCR (lowest) values were obtained by the D55 and $50 \% \mathrm{CP}$ groups followed in an insignificant $(\mathrm{P}<0.05)$ increasing order (worth) by D45 and D40\%CP groups, respectively. As presented in the same table, the highest PER value (1.73) was recorded by the D55\%CP group followed in a significance decreasing order by D50\%CP, D40\%CP and D45\%CP groups, respectively. Concerning the PPV\% values, the groups D55 and D50\% CP recorded the highest $(\mathrm{P}<0.05)$ values as compared to the D45 and D40\% CP groups. However, insignificant differences were found for the hepatosomatic index (HIS) among dietary treatments.

\section{Carcass analysis}

Proximate composition of whole fish body analysis did not change significantly in terms of dry matter, crude protein, crude lipid and ash contents by different dietary treatments (Table 7). However, whole fish body lipid was slightly increased by the increasing dietary protein and lipid levels in the diets without significant differences $(\mathrm{P}<0.05)$ between the dietary treatments.

Table 7: Carcass analysis of Solea aegyptiaca fed the experimental diets (\%w/w basis).

\begin{tabular}{|l|c|c|c|c|c|}
\hline \multirow{2}{*}{ Items } & \multicolumn{5}{|c|}{ Diets } \\
\cline { 2 - 6 } & Initial & $\mathbf{D 4 0}$ & $\mathbf{D 4 5}$ & $\mathbf{D 5 0}$ & $\mathbf{D 5 5}$ \\
\hline Dry matter & 28.0 & $28.1^{\mathrm{a}}$ & $28.6^{\mathrm{a}}$ & $28.5^{\mathrm{a}}$ & $28.6^{\mathrm{a}}$ \\
\hline Protein & 19.6 & $19.3^{\mathrm{a}}$ & $19.4^{\mathrm{a}}$ & $19.4^{\mathrm{a}}$ & $19.2^{\mathrm{a}}$ \\
\hline Lipid & 5.4 & $5.3^{\mathrm{a}}$ & $5.4^{\mathrm{a}}$ & $5.6^{\mathrm{a}}$ & $5.5^{\mathrm{a}}$ \\
\hline Ash & 3.0 & $3.5^{\mathrm{a}}$ & $3.8^{\mathrm{a}}$ & $3.5^{\mathrm{a}}$ & $3.9^{\mathrm{a}}$ \\
\hline
\end{tabular}

Means in the same raw with different super script letters are significantly different $(\mathrm{P}<0.05)$.

\section{DISCUSSION}

Knowledge of feeding requirements of the culture fish species are key issues to design accurate feeding strategies, maximizing food intake and minimizing food waste. Moreover, feeding fish according to their appetite leads to improve growth and feed efficiency. The protein requirement of juvenile sole is still scarce and generally fed with a commercial diet used in other marine species such as troubt, seabream and seabass, whether these commercial diets are optimal to juvenile sole is still unknown, hence it is reasonable to formulate a specific diet for on-growing sole.

The proximate composition of silverside (Atherina boyeri) meal from protein, amino acids and fatty acids showed that it is good nutrient that could be utilized by sole. The high protein contents and moderate lipid levels in (Atherina boyeri) are similar to that found in the same species by Bouriga et al. (2010) and other species such as Sardine (Bandarra et al.2001) and Sarda (Zaboukas et al. 
2006). The highest concentration of both glutamic acid and threonine are in agreement with previous studies (Adeyeye, 2009, Bouriga et al.2010 and Selmi et al.2010). The high proportion of n-3 PUFA was found in this study are in agreement with results recorded by Osman et al. (2001), Passi et al. (2002) and Bouriga et al. (2010). The experimental diets used during the present study were formulated to have different protein and energy levels. The diets were prepared to cover a range of protein levels for this species to determine which level can be optimum for growth performance. These results further confirmed the feasibility of using silverside meal in the feed formulation of sole due to less cost and palatability to this species.

Cowey (1992) stated that the weight gain and protein utilization are important criteria, when evaluating protein requirements of trout, since protein utilization should be preferred in estimating than those related to weight gain. The highest weight gain, average weight gain, specific growth rate and condition factor of sole fed the D55\%CP declared that this percent can meet the requirements of this species. Subhadra et al. (2006) suggested that fish growth efficacy can be affected by diet composition and feeding trial duration. Similar results from gain, specific growth rate and condition factor were recoded in the same species by Bonaldo et al. (2006), Rudea-Jasso et al. (2004) and Silva et al. (2010). The present study showed that feed conversion ratio was significantly affected by dietary protein levels. Sole fed D55\%CP gave the best feed conversion ratio compared with the other diets. Comparable feed conversion ratio was reported in sole by Bonaldo et al. (2006) and Gatta et al. (2010). On the other hand, the feed utilization values of proteins were well utilized by fish fed different protein levels, where PER and PPV\% achieved the highest values for the D55\%CP and then reduced in D40\%CP. Similar results were recorded in Solea senegalensis (Rema et al., 2008) and other flatfish species such as Atlantic halbut and turbot (Regost et al., 2001) and Hatlen et al., 2005). The HIS is often used as an indicator of condition and nutritional status of fish. The HSI values gain during the present study was similar to the values recorded for Solea senegalensis (Silva et al., 2010 ).

Growth performances data declare that $55 \%$ crude proteins is optimal to meet the requirements of Solea aegyptiaca. This result be within the ranges of the previous requirements confirmed for optimum requirements of sole as $53 \%$, $55 \%$ and $57 \%$ by Rema et al. (2008), Coutteau et al. (2001), and Gatta et al. (2010), respectively. The slight tendency toward a higher feed intake in D40\%CP can be explained as the sole compensated for the differences in dietary protein levels by adjusting their intake. The same finding has earlier been reported in other fish species Grisdale-Helland et al. (2008), Toppe et al. (2006), Burr et al. (2006) and Yones (2005 \& 2010). The carcass proximate composition of sole, indicated that the dry matter, protein, lipid and ash were not affected by the different diets. Similar results have been reported for sole (Dais et al.,2004), Rema et al., 2008 and Gatta et al., 2010). 
In conclusion, our results confirm that for a typical practical diet formulation with 55\% CP is adequate for meeting the requirement of juvenile Solea aegyptiaca. This study also declared the feasibility of using silverside meal in the feed formulation as alternative and cheap protein source to fish meal in feeding sole, due to less cost and palatability of this species.

\section{REFERENCES}

Adeyeye, E L.(2009). Amino acid composition of three species of Nigerian fish Clarias anguillaris,Oreochromis niloticus and Cynoglossus senegalensis. Food Chem.,113:43-46.

AOAC (1995). Association of Official Analytical Chemists 14ed. Assoc Office, Anal. Chem, Washington, Dc.

APHA (1992). Standard methods for the examination of water and waste water. American Public Health Association, Washington, DC, 1134pp.

Aksnes, A.; Hjertnes,T. and Opstvedt, J. (1996). Effect of dietary protein level on growth and carcass composition in Atlantic halibut (Hippoglossus hippoglossus L.). Aquacult., 145: 225-233.

Appelbaum, S. (1985). Rearing of Dover sole Solea solea L. throught its larval stage using artifical diets. Aquaculture, 49: 209-221.

Bandarra, NM.; Batista, I.; Nunes, ML. and Empis, J.M. (2001). Seasonal variation in the chemical composition of Horse Mackerel (Trachurus trachurus). Eur. Food Res. Technol., 212 : 535-539.

Berge,G. M. and Storebakken, T. (1991). Effect of dietary fat level on weight gain, digestibility and fillet composition of atlantic halibut. Aquaculture, 99: 331-338.

Bernardo, J. (1990). Dinamica de una lagoa Costeria eutrofica (lagoa di Santo andre) Ph.D. Thesis, Faculdade de Ciencias universidade de Lisboa, Portugal.

Blauth, D.J.; Chareinski, M. and Drelic, H. (1963). A new rapid method for determining tryptophan. Anal. Chem. 96-99.

Bonaldo, A.; Roen, A.J.; Pecchini, A.; Grill, E. and Gatta, P.P. (2006). Influnce of dietary soybean meal levels on growth, feed utilization and gut histology of Egyption Sole (Solea aegyptiaca) juvenile. Aquacult., 261: 580-586.

Bouriga, N.; Selmi, S.; Faure, E. and Trabelsi, M. (2010). Biochemical composition of three tunisian silverside fish populitions caught in open sea, lagoon and island coasts. African J. of Biotechn., 9 (26): 414-419. 
Braber, L. and de Groot, S. J. (1973). The food of live flatfish species (Pleurone ctiforms) in the northen. North sea, Neth. J. Sea Res., 6: 163-172.

Bromley, P. J. (1977). Methods of weaning Juvenile hatchery reared Sole (Solea solea L.) from live food to prepared diets. Aquacult., 12: 337-347.

Burr, G.S.; Peng, L.P.; Gols, B.; Gohn, D.M.; Grsdle-Helland, B. and Helland, S. J. (2006). Evaluation of growth and whole body composition of juvenile hybrid striped bass (Morone chrysops $\times$ M. Ssaxutilis) and red drum (Sciaenops ocellatus) fed high-protein and high-lipid diets. J. World Aquac. Soc., 37: 421-430.

Cabral, H. and Costa, M.G. (1999). Differental use of nursery areas within the Tagus Estuary by sympatric soles Solea solea and Solea senegalensis. Environ. Biol. Fish, 56: 389-397.

Cadena-Roa, M.; Huelvan, C.; Le Borgne, Y. and Metailler, R. (1982). Use of rehydrated extruded pellets and attractive substances for weaning of Sole (Solea vulgaris). J.World Maric. Soc., 13: 246-253.

Coutteau, P.; Robles, R. and Spruyt, W. (2001). Ongrowing feed for Solea senegalensis Kaup, 1858. In abstract of contribution presented at the international conference, Aquaculture Europe 2001. Special publication no, 29.Europe Aquacult. Socity pp 58-59.

Cowey, C.B. (1992). Nutrition estimating requirements of rainbow trout. Aquacult., 100:177-189.

Dais, J.; Rueda-Jasso, R.; Ponserat, S.; Conceicao, L.E.C.; Gomes, E.F. and Dinis, M. (2004). Effect of dietary carbohydrate to lipid ratios on grouth, lipid deposition and metabolic hepatic enzymes in juvenile Senegalese sole (Solea senegalese, Kaup). Aquacult. Res., 35:1122-1130.

Day, O.J.; Howell, B. R. and Jones, D.A. (1997). The effect of dietary hydrolysed fish protein concentrate on the survival and growth of Dover sole Solea solea (L) during and after weaning . Auacult. Res., 28: 911-922.

Day, O. J.; Howell, B. R.; Aksnes, A. and Nygard, E. (1999). Recent advances in the weaning of Sole Solea solea (L). In Abstract of contributions presented at the international conference aquaculture Europe, 1999. Special publication,27 European Aquacult. Society, pp. 40-41.

Dinis, M.T.; Ribeiro, L.; Soares, F. and Sarastuele, C. (1999). A review on the cultivation potential of Solea senegalensis in Spain and Portugal. Aquacult., 176: 27-38. 
Duncan, D.B. (1955). Multiple ranges and multiple F. test. Biometric, 11: 1-42.

Eisawy, A. and El-Bolock, A. (1975). Status of aquaculture in the Arab Republic of Egypt. Symposium on aquaculture in Africa, Ghana, 30 Sept. -2 Octob., 1975.

El-Shabrawy, G. M. and Ahmed, K. N. (2007). Seasonal and long term changes of macrobenyhos in lake Qarun. Egypt J.Acad. Soc. Environ. Develop., 8 (3): 1-15.

Fabre-Domergue, P. and Bietrix, E. (1905). Development de la Sole (Solea vulgaris). Travial du laboratio de Zoologie Maritime de Concarneau Vuibert et Nony, Paris, 243pp.

Folech, J.; Lees, M. and Sloane Stanley, G. (1957). A simple method for the isolation and purification of total lipids form animal tissues, J. Biol. Chem. 226: 497-509.

Fonds, M. (1976). The influence of temperature and salinity on growth of young sole Solea solea L. Eur. Symp. Mar. Biol., 1:109-125.

Gardner, W.S. and Miller, W.H. (1980). Reverse phase lipid chromatography of amino acids after reaction with opthaladehyde. Anal. Biochem., 101: 61-70.

Gatta, P.P.; Parma, L.; Guarmiero, I.; Mondrioli, L.; Sirri, R.; Fontanillas, R. and Bonaldo, A. (2010). Growth, feed utilization and liver histology of juvenile common Sole (Solea solea L.). fed isoenergetic diets with increasing protein levels. Aquacult. Res., 1-10.

Grisdale-Helland, B.; Shearer, K.D.; Gatlin, D.M. and Helland, S.G. (2008). Effect of dietary protein and lipid levels on growth, protein digestibility, feed utilization and body composition of Atlantic cod (Gadus morhua). Aquacult., 283:156-162.

Guillaune, J.; Caustans, M.; Metailler, R.; Person-Le Ruyet, J. and Rebin, J. (1991). Flatfish, trbot, sole and plaice. In: Wilson,R $>$ P. (ed), Hand book of Nutrient Requirement of Finfish CRC, Press, Boca, Raton, Florida, pp. 77-82.

Hatlen, B.; Grisdale-Helland, B. and Helland, S.G. (2005). Growth, feed utilization and body composition in two size groups of Atlantic halibut (Hippoglossus hippoglossuus) fed diets differing in protein and carbohydrate conten. Aquacult.,249: 401-408.

Howell, R. R. (1997). A re-approisal of the potential of the Sole Solea solea L. for commercial cultivation. Aquaculture,155: 359-369. 
Jobling, M. (1994). Fish bioenergetics, Series,13 published by Chapman \& Hall-2-6 Boundary, R, London SBI 8HN, 300pp.

Kariman, A.S. (2009). Some observation on fisheries biology of Tilapia zillii (Gervais,1884) and Solea vulgaris (Quensel,1806 in lake Qarun, Egypt. World Journal of Fish and Mar. Sci.,1:20-28.

Knutsen, J. A. (1992). Feeding behavior of North sea turbot (Scophthalmus maxinus) and Dover sole (Solea solea) larvae elicited by chemical stimuli. Mar. Biol., 113: 543-548.

Lozano, N.B.S.; Vidal, A.T.; Martinez-Llorens, S.; Merida, S.N.; Blanco, J. E.; Lobez, A. M.; Torres, M.P. and Cerda, M.J. (2007). Growth and economic profit of gilthead sea bream (Sparus aurata L.) fed sunflower meal. Aquacult., 272: 528-534.

Mehanna, S.F. (2007). Stock assessment and management of the Egyption sole (Solea aegyptiaca Chabanaud, 1927, Osteichthyes: Soleidae) in the southeastern Mediterranean, Egypt. Turk. J. Zool., 31: 379-388.

Metailler, R.; Menu, B. and Moriniere, P. (1981). Weaning of Dover sole (Solea vulgaris) using artifical diets. J. world Maricul. Soc.,12: 111-116.

Metailler, R. Cadena-Roa, M. and Person-Le Ruyet, J. (1983). Attractive chemical substances for the weaning of Dover sole Solea vulgaris: qualitative and quantitative approach. J.World Maricult.Soc.,14: 674-584.

Osman, N. H.; Suriah, A.R. and Law, E.C. (2001). Fatty acid composition and cholesterol content of selected marine fish in Malaysian water. Food Chem., 73:55-60.

Passi, S.; Cataudella, S.; Dimarco, P.; De Simone, F. and Rastellii, L. (2002). Different Mediterranean species of fish and shellfish. J. Agr.Food Chem., 50: 7341-7322.

Piccolo, G.; Morono, S.; Bovera, F.; Tudisco, R.; Caricato,G. and Nizzo, A. (2008). Effect of stocking density and protein/fat ratio of the diet on growth of Dover sole (Solea solea). Aquacult. Res., 39: 1697-1704.

Regost, C.; Arzel, J.; Cardinal, M.; Robin, J.; Loroche, M. and Kaushik, S.J. (2001). Dietary lipid levels, hepatic lipogenesis and flesh quality in turbot (Psetta maxima). Aquacult., 193: 291-309. 
Rema, P.; Conceicao, L.E.C.; evers, F.; Costro-Cunha, M. Dinis, M.T. and Dias, J. (2008). Optimal dietary protein levels in Juvenile Senegalese sole (Solea senegalese). Aquacult. Nutr.,14: 263-269.

Rubio, V.C.; Navarro, D.B.; Madrid, F.J. and sanchez-Vasquez, F.J. (2009). Macronutrient self -selection in Solea senegalese-fed macronutrient and challenged with dietary protein dilution. Aquacult.,291: 95-100.

Rueda-Jasso, R.; Conceicao, L.E.C; Dias, J.; De Cone, Gomes, E.; Rees, J.F.; Soare, F.; Dinis, M.T. and Sorgeloss, P. (2004). Effect of dietary non-protein energy levels on condition and oxidative status of Senegalese sole (Solea sengegalensis) juveniles. Aquacult., 231: 417-433.

SAS (1986). SAS User's Guide Version 6 Edition. SAS Institute,Cary,NC.USA.

Sabrah, M. M. (2004). Food and feeding habit of Solea solea from Bardawil lagoon, Egypt. International Conference Biological. Science, 3: 1227-1248.

Selmi, S.; Bouriga, N.; Cherif, M.; Toujami, H. and Trabelsi, M. (2010). Effect of drying process on biochemical and microbiological quality of silverside fish (Atherina lagunae). International Journal of Food Science and Technology, 45: 1161-1168.

Shantha, N.C. and Ackman, R.G. (1990). Nervoric acid versus tricosanoic acid as internal standards in quantitative gas chromatographic analyses of fish oil longer chain n-3 polyunsaturated fatty acid methyl esters. J.Chromatogr. 533:1-10.

Shelbourne, J.E. (1975). Marine fish cultivation: pioneering studies on the culture of larvae of the plaice (Pleuronectes platessa L.) and the Sole (Solea solea L.). Fisheries and Food Fishing investigation, SeriesII, 27(9).Her Majestys stationary Office, London, 29 pp.

Silva, J.M.G.; Espe, M.; Conceicao, I.EC.; Dias, J.; Costa, B. and Valente, L.MP. (2010). Feed intake and growth performance of Senegalese sole (Solea senegalese Kaup,1858) fed diets with partial replacment of fish meal with plant proteins. Aquacult. Nutrition, 41: e20-e30.

Snedecore, W.G. and Cochran, W.C. (1987). Statistical Methods. Iowa state Univ., USA.

Subhadra, B.; Lochmann, R.; Rawles, S. and Chen, R. (2006). Effect of dietary lipid source on growth, tissue composition and hematological parameters of largemouth bass (Micropterus salmoides). Aquacult., 255:210-222. 
Toppe, J.; Aksnes, A.; Hope, B. and Albrektsen, S. (2006). Inclusion of fish bone and crab by-products in diets for Atlantic cod, Gadus morhue. Aquacult., 253: 636-645.

Windsor, M.L. (2001). Fish meal. Department of trade and industry, Torry Research Station. Rep.No,49,FAO, http//www.fao.org./wairdocs/tan x5926e01htm.

Yones, A. M. (2005). Inclusion of lupin seed meal as plant protein source in gilthead sea bream (Sparus aurata) diets. J. Agric. Sci. Mansoura Univ. 30 9(11): 65536564.

Yones, A. M. (2010). Effect of lupin kernel meal as plant protein sources in diets of red hybrid tilapia (Oreochromis niloticus $\times$ O.mossambicus), on growth performance and nutrients utilization. African J. Biol.Sci.,6 (1):1-16.

Zaboukas, Milliou, H.; Megalofonou, P. and Moraitou-Aposolopoulou, M. (2006). Chemical composition of Atlantic bonito Sarda sarda from the Aegean sea (eastern Mediterranean sea) in different stages of sexual maturity. J. Fish Biol., 69: 347-362. 